\title{
Apresentação: dossiê "O Ensino de História”
}

Os desafios que envolvem, contemporaneamente, pensar a história e seu ensino constituem o nexo em torno do qual foi organizado o presente dossiê “O Ensino de História” da Revista "Em Tempo de Histórias”, com artigos de pesquisadores de instituições do Brasil e de Portugal.

A concepção de que a história é plural, assim, como o passado que narra, e de que não é possível reduzi-lo a uma única forma e conteúdo, tampouco seu ensino, norteou a concepção do dossiê. Os artigos que integram são leituras produzidas por historiadores/as de diferentes lugares de fala e encerram, naquilo que incluem e excluem, uma localização e um modo de inteligibilidade diante do tema ensino de história. Objeto, esse, que apesar e por conta de sua permanente e familiar presença em nosso fazer cotidiano, sempre nos escapa. Com efeito, tal como uma indecifrável esfinge que nos afronta e nos confronta, somos por ele cotidianamente interpelados e convocados, por um "dever de ofício", a pensar e repensar nossas práticas docentes no esforço de responder a três questões primeiras: por que ensinar história? quais histórias ensinar? como ensiná-las?

Em interessante exercício de reflexão investigativa acerca de “como a história é percebida pelos alunos” um grupo de pesquisadores da Universidade de Porto - Luís Alberto Marques Alves, Cláudia Pinto Ribeiro, Renato Magalhães Oliveira e Laura Castro Moreira procura resposta e indica alguns caminhos, possibilidades, para aquelas questões. No artigo “Ideias de alunos sobre o 'seu’ passado doloroso: a Guerra Colonial Portuguesa”, seus autores, ao relatar sua pesquisa e seus resultados, ressaltam a importância de um ensino de história que fomente nos jovens a "reflexão e o espírito crítico". Para eles, estas seriam competências indispensáveis a serem buscadas no ensino da disciplina, pois permitem "abrirlhes a porta da consciência histórica, potenciar a compreensão do presente e garantir que o futuro não será fruto de uma visão monolítica”.

Em "História e sociedade: da política e da cidadania como molas vitais para o fazer histórico”, Manoel Santos Mota faz uma instigante e politizada reflexão acerca das relações entre cidadania, educação e ensino de história. Ao analisar a "história na sala de aula”, o autor aposta no potencial transformador da disciplina e de seu ensino no projeto contemporâneo de “humanização do ser humano”. Investe, assim, na ideia do ato educativo como ação que 
deveria estar orientada para a construção da cidadania e da democracia, concepções e práticas políticas indissociáveis e em constante (re)elaboração.

Uma proposta de ensino centrada em metodologias que estimulem e possibilitem o protagonismo dos/as alunos/as na aprendizagem dos conteúdos históricos, tendo como ponto de partida o reconhecimento de sua localização na história, é o que nos apresenta Jorge Artur Caetano Lopes dos Santos. Em seu artigo "Recanto de Memórias: estudo de representações do Recanto das Emas”, ele nos mostra que é possível “ampliar as práticas de ensino da história e ensinar diferentes modos de refletir historicamente”, descartando o reducionismo de uma única abordagem teórica e metodológica da história e de seu ensino.

A Guerra do Paraguai foi o tema priorizado por André Mendes Salles na análise comparativa de duas edições do livro didático "História Global: Brasil e Geral” (1999 e 2005), de Gilberto Cotrim. O estudo feito evidencia que, contrariamente ao reiterado no senso comum, ocorre uma efetiva aproximação entre o saber acadêmico e o saber escolar. Como explicita o autor, no que tange à Guerra do Paraguai, houve uma incorporação atualizada das discussões e reflexões historiográficas na revisão feita por Cotrim para a edição de seu livro, em 2005.

Na direção oposta reflete Rogério Lustosa Victor, ao expor a invisibilidade e mesmo ausência da perspectiva da diversidade e igualdade étnico-racial nas narrativas didáticas sobre a sociedade brasileira. No artigo de sua autoria, "Ensino de História: o livro didático e a questão do outro”, ele questiona as possibilidades de formação de uma consciência histórica democrática em meio a um ensino de história e de livros didáticos que ignoram a "questão do outro”, que constroem um silêncio em torno da questão da diversidade e da diferença.

No artigo "Ensino de História e a temática indígena: o uso do cinema na sala de aula.”, sua autora - Laís Alves Sanchez - propõe justamente o contrário: visibilidade do outro, respeito às diferenças e à diversidade na história e em seu ensino. Como o próprio título indica, a autora ressalta o potencial didático dos filmes, percebidos como narrativas plenas de possibilidades. A novidade apresentada pela autora é a de pensar, a partir da linguagem cinemática, que constrói/descontrói nossos valores, idéias, representações e significações, “o lugar e o papel que os povos indígenas ocupam na história do Brasil”.

Finalmente, mas não menos importante, o último artigo do dossiê, de autoria de Claudia Regina dos Santos. Sob o título "Novas abordagens do ensino de História: as linguagens artísticas na sala-de-aula”, ela propõe e defende um aprofundamento dos diálogos entre história e linguagens artísticas, particularmente o teatro e a música, como orientações 
para as práticas didáticas cotidianas. A autora valoriza a perspectiva interdisciplinar, ao ressaltar que esta permite acessar "vivências e dilemas políticos e sociais de uma determinada época da história do Brasil”. O manuseio que o/a aluno/a faz de linguagens peculiares facilita a aprendizagem dos conteúdos históricos e sobretudo a compreensão da historicidade da sociedade e da cultura, localizando-se também, ele/ela, na história.

Ao sublinhar a singularidade de cada análise, estou também, como os autores e autoras, questionando o unívoco na história e investindo na pluralidade, no entendimento da história e de seu ensino como campos de múltiplas possibilidades. Convidamos você, leitor(a), para também enfrentar esse desafio.

Diva de Couto Gontijo Muniz ${ }^{1}$

Universidade de Brasília

${ }^{1}$ Professora do Departamento de História e do Programa de Pós-Graduação em História da Universidade de Brasília (UnB). 